\title{
Beauty in the 'world outside' is most pure imperfect. The Anti-Iconography of the Friedsam Annunciation (attr. van Eyck).
}

\author{
Camille Akmut
}

Working paper.

\begin{abstract}
The analysis of Annunciation, a 15th c. painting of unclear origins, attributed to either Jan van Eyck, his circle or Petrus Christus, sheds some light on the characteristics, acts of heroes - their mirror to us.
\end{abstract}


"Because of this, I/O proved to be a thorny issue for functional programmers for some considerable time" (Simon Thompson, The Craft of Functional Programming..., p. 182) 


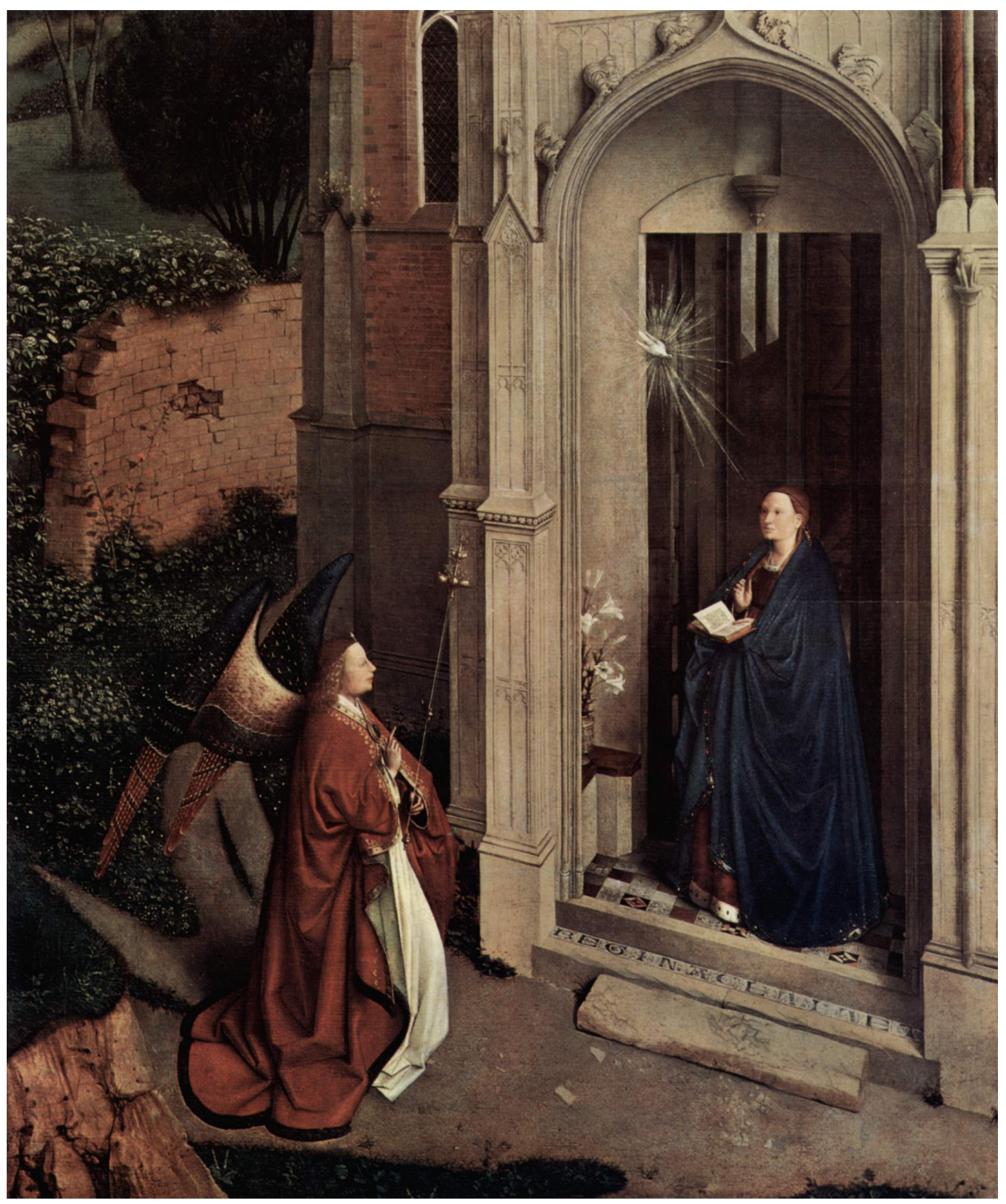

Figure 1: The "Friedsam" Annunciation 


\section{Beauty in the 'world outside' : an essay in anti-iconography}

The so-called "Friedsam Annunciation" - as Russel stylizes it. We prefer "the "friedsam" Annunciation" ourselves.

Our heroes have many, many faults - but none of them unforgivable. For, if we had to blame them, we would have to blame ourselves. And, those who would throw stones at them, let us say one found in and around the grounds of the church that can be seen in the Friedsam Annunciation, they would have to throw them at themselves. Both acts we know to be both illogical and impossible.

Malcolm X had lived a life of great debauchery before becoming who we know him to have become : an uncompromising, unforgiving voice for the voice-less of his times; he had pushed it so far he was killed. In defense of him, the immensely great writer James Baldwin had said :

"If we were white, if we were Irish, if we were Jewish, if we were Poles, if we had in your mind a frame of reference, our heroes would be your heroes too. Nat Turner ${ }^{1}$ would be a hero for you, instead of a threat. Malcolm X might still be alive. And, you know, everyone is very proud of brave little Israel - a State I have nothing against, I don't want to be misinterpreted, I am not an antisemite - but when the Israelis pick up guns, or the Poles, or the Irish, any white man in the world says "Give me liberty or give me death", the entire white world applauds. When a black man says exactly the same thing, word for word, (...) everything possible is done to make an example of this "bad nigger". So, that there won't be anymore like him." 2

By the best of our information ${ }^{3}$, the great sociologist Pierre Bourdieu had lived with the burden - real or imagined - of being or feeling responsible for the death of someone (the death by suicide we believe of his girlfriend). And, perhaps, by doing what he had done, and liberating countless others, he had paid back his debt. And, not only that, but he had done so, so many times, over and over again, that he had transcended whatever was left, but presumably not or never forgotten, for such things are not easy, nor easily forgotten.

Michel Foucault, who had to grow up as a young gay man in the highly intolerant culture of the 1950s, a situation he could not escape, for we cannot escape our times, no more than we can ourselves, had developed various extraordinary behaviors that were normal abnormal reactions to abnormal circumstances ${ }^{4}$. In the Middle Ages, that of Christianity to be clear, it was the norm to burn people like him - down to the bones.

\footnotetext{
${ }^{1}$ Early 19th century slave, who lived to be 30 years old, and figuratively, though perhaps also literally, put a rope around his master's neck, and bent forward until the work was done - and in doing so liberated thousands others.

${ }^{2}$ Raoul Peck, I Am Not Your Negro (2016).

${ }^{3}$ This we base on now distant memories of conversations with 2,3 , possibly 4 of people who knew him then. We have nothing to add, and nothing left other than what we write here.

${ }^{4}$ If the writings of Huxley are to be followed.
} 
If we had to blame our heroes, and task so illogical and impossible, we would have to start with ourselves, a task even more impossible, for "we cannot think outside of logic" according to one philosopher and historian of science, Jean Cavailles.

But, let us continue for a while, before we get to the Annunciation attributed to van Eyck. Our fine gentlemen and gentlewomen out of the oh-so fine area of art history, will give us the benefit of the doubt, and be silent for a while - until we are done.

In fact, let us take an example that will be closer to them, and simultaneously bring us closer to Van Eyck.

Rembrant van Rijn, this great master, even among the many masters that were not lacking in the Golden age of oil painting, had perfected the techniques of his times to such degrees - that everything pales next to him. The helmet in "The Man with The Golden Helmet", the honorary clothing worn by various noble ladies and dames, the masterfully rendered creases and folding of their clothing, and the jewels around their necks, the immanent social critic present in the Old man surrounded by books. This great, great master among masters. There will never be someone again like him - he is impossible to think in our times, nor would he be greatly needed.

But, let us talk about Rembrandt, the man, in his times. To the best of our knowledge, again ${ }^{5}$, Rembrandt was what can be described and would now be described commonly as a "ladies' man" - or a gigolo depending on one's view of the world : a man of many, often conflicting proclivities. A man of high libido and "moral faults", who often thought with all the wrong parts of his body, his human body, this human body of his. Let's not waste time here :

Rembrandt sure had made a many promises to a many poor, young town or village girl in his days. And, as was the custom of the time, such dumb, dumb little girls - he must have thought of them so himself - could be done away with easily under the premise or pretense of "folly". And our master, this great master among masters, had done no less : in this way, he reminds us of the bon-vivant figures of our times, such as Dominique Strauss-Kahn. Mistresses : willing and unwilling alike. Thrown away like trash when, once they were done with them.

Is this perhaps why his self-portraits show him so tortured?

And, we could write a many things about a many professors at Oxford, but we prefer to talk about our times, as we can only live in them :

Edward Snowden, a hero who makes it so hard for us to love him with a full heart, and we cannot bring ourselves to love so, had opinions and visions of our society so outlandish, he deserves a kick.

But, as we have said : a debt paid - a kick to him is one to ourself/ourselves.

${ }^{5}$ This is, this time, based on a large volume whose title we can only give here as The Master and (or in) his atelier. 


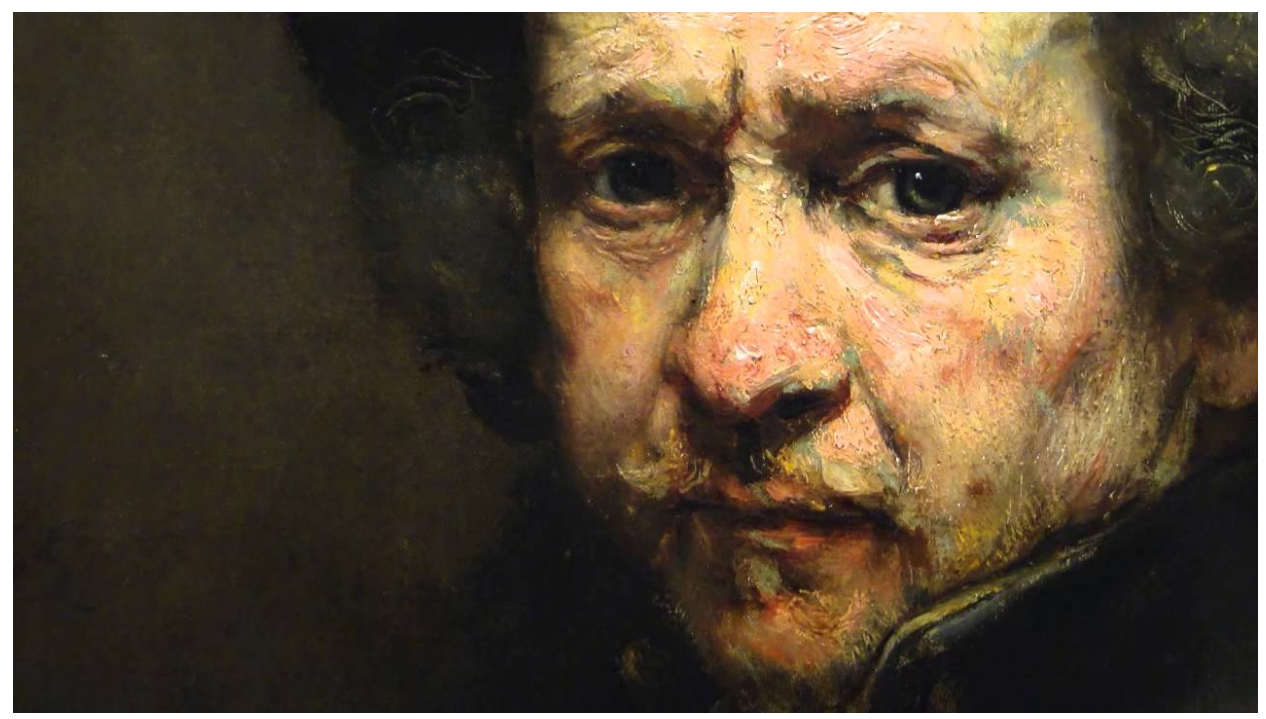

Figure 2: Rembrandt, Self-Portrait.

Let us now finally come to this great painting of uncertain origins.

As John Malcolm Russel writes ${ }^{6}$, this painting has been attributed variously, but primarily to three sources : either Van Eyck himself, his Circle $^{7}$, or, though we think this unlikely due to differences in styles and technical mastery, Peter Christus, mentioned last.

No matter its creator, the origins of which our art historians may one day agree on, and perhaps so with the use of (new) technologies, its content is of greater interest to us here.

For this Annunciation is very much like our heroes. Imperfect - and all the more human and beautiful.

Indeed, as we argue : In the 'world outside', there is no purity and beauty is most imperfect.

The formal beauty, that is so great in the Friedsam Annunciation, so great that we are inclined to attribute it to Van Eyck only, for Van Eyck, like Rembrandt, had perfected oil painting better than any of his contemporaries : this beauty of forms sits atop great audacity, eccentricity and decay.

Beauty, again, is most, strongest, when imperfect we argue : a nose too big - a criterion of great beauty in fact in previous ages or eras but now the exact contrary ${ }^{8}-$, a scare on an otherwise perfect face or body, a mix of feminine and masculine, body parts that don't fit.

This so-called "Friedsam Annunciation" is very much likewise. And, it is precisely that, that makes it so touching and close to us, in this 21 st

\footnotetext{
${ }^{6}$ Russel $1978: 24$.

${ }^{7}$ Russel cites Hubert (Hubert van Eyck, older brother of Jan).

${ }^{8} \mathrm{So}$, in the paintings of the 15 th c. Italian painter Botticelli, we think of Primavera in particular. And, for their modern-day counterpoint, see Vogue.
} 
century of ours, that is so full of contradictions.

An inscription at the foot of this church, look at it, says : R E G I N $\mathrm{A} \mathrm{C} \mathrm{E}$, and then it comes hard to read.

Through Russel, we know : "REGINA CELI[ARE]" or "Queen of Heaven, Rejoice."

Notice how the overgrown garden threatens to enter the church, this most sacred place, receptable and college of our sins, real and imagined.

The archangel Gabriel, he/him, they/them, she/her, has monstrous inhuman wings and a golden sceptre sign of balance or violence.

"The Friedsam Annunciation is an image of transition." says Russel, who, not even in his wildest dreams, could have imagined this would be interpreted in this way.

The wall behind them, it has often been noted already, is in a state of some, up-to great decay. Should it one day fall, it would threaten the very foundations of the church.

Panofsky, the arguably greatest scholar of and authority on Van Eyck, that "even his errors are beautiful" writes, proposes that:

"The title of the present publication is, like most titles, inaccurate. I have not attempted a presentation of Early Netherlandish Painting in its entirety - a task which will have to wait, I believe, for another Max J. Friedlander or Hulin de Loo".

We never enjoy the history, the social history, the sociology of art, the historical sociology of art, than under the guidance of Panofsky, who "reminds us that at this time right was still considered "right," while left had sinister or evil implications." as Russel points out. - an observation of so many implications and complications for our times, though it remains the opinion of this author that, "friedsam", or "gewaltsam", when we liberate ourselves we start from the bottom. (On the left.)

The church itself is most imperfect : a bastard mix, one sitting on top, or alongside the other, Gothic and else. - parts that don't fit together.

The "Friedsam" Annunciation, let us be clear about this, is not a peaceful one : it is a violent, truthful, beautiful, pure celebration of all the bastard dogs with no names, the women with noses too big, or bellies fat, of trans-men and trans-women, passing non-passing, "transitioning" and not, "niggers", "negroes" and "niggas", real and bad, dark black and half, free modifiers of hardware and software, and the many, many others. - you, cowards, keep erasing them, we put them back. Our people. 


\section{Acknowledgement}

To my dad, self-taught painter (oil, gouache, some watercolor), in the style of the impressionists and expressionists according to descriptions.

\section{Bibliography}

-. "When we liberate ourselves we start from the bottom. Introduction to an upcoming report on coreboot, Libreboot and Panfrost."

Russell, John Malcolm. 1978. "The Iconography of the Friedsam Annunciation". The Art Bulletin 60(1) : 24-27.

Panofsky, Erwin. Early Netherlandish Painting. Its origins and character. 